Медіафорум : аналітика, прогнози, інформаційний менеджмент : зб. наук. праць. - Чернівці :

Чернівецький нац. ун-т, 2020. -

Том 8. - C. 165-172
Mediarorum: Analytics, Forecasts, Information Management: Collection of Research Articles. - Chernivtsi: Chernivtsi National University, 2020. Vol. 8. - pp. 165-172

https://doi.org/10.31861/mediaforum.2020.8.165-172

УДК: 378.018 .43

(C) Валентина Богатирець ${ }^{1}$

\title{
BENEFITS OF HYFLEX LEARNING IN CREATING A POSITIVE STUDENTS' EXPERIENCE ${ }^{2}$
}

During the COVID-19 pandemic HyFlex teaching/learning has increasingly grown into a crucial feature of education. My strong conviction is the integration of information technology in education will be further accelerated and online education has eventually become an integral component of the present-day education. Despite the drawbacks, there are some obvious benefits to leveraging a HyFlex course model. It allows students more flexibility than ever before, meaning they can adjust and adapt as needed to accommodate their schedules (in our case, being in Ukraine or abroad). It also gives students access to a greater breadth of learning materials than they would otherwise receive. It is worth mentioning that after Covid-19 the world and education has changed dramatically, with the distinctive rise of e-learning, whereby teaching is undertaken remotely and on digital platforms. This resulted in the largest "online movement" in the history of education. Importantly, research suggests that online learning has been shown to increase retention of information and less time-consuming, means the changes Coronavirus have caused will be here to stay.

Key words: HyFlex teaching/learning, students, Covid-19, flexibility, adaptability, positive experience, hybrid online course.

1 Кандидат політичних наук, доцент кафедри сучасних іноземних мов та перекладу факультету історії, політології та міжнародних відносин Чернівецького національного університету імені Юрія Федьковича. E-mail: v.bohatyrets@chnu. edu.ua; http://orcid. org/0000-0002-6291-5180

2 Thesis of Inter-University Videoconference on 'Innovative Teaching Methods', arranged by the Department of Philology, Translation Studies and Strategic Communications of National Academy of the National Guard of Ukraine, Kharkiv, Ukraine, December, 21,2020 


\section{Переваги змішаного навчання у процесі створення сприятливих} умов для навчання студентів

Під час пандемії COVID-19 змішане викладання/навчання стрімко трансбормувалося у якісно нову гібридну методику навчання. Варто зазначити, щз інтеграція інформаційних технологій в освіту відбувається досить швидко, і наразі онлайн-освіта стала невід'ємною складовою сучасної освіти. Незважаючи на певні недоліки, використання моделі змішане викладання/навчання має кілька очевидни переваг. Це дає студентам більше гнучкості у процесі навчання, тобто, вони можуть пристосовуватися та адаптуватися за необхідності до зручного графіку та режиму навчання (у нашому випадку, перебуваючи як в Украӥні так і за ї межами). Варто зазначити, що після Covid-19 світ та освіта кардинально змінилися, а саме змінилися форми навчання, які здійснюються дистаниійно та на різних сучасних иифрових платформах. Це призвело до потужної та всюдисущої «онлайн-революиї» в історії освіти, яка матиме позитивні наслідки для подальшого вдосконалення освітнього процесу в умовах пандемії.

Ключові слова: змішане викладання/навчання, студенти, Covid-19, гнучкість, адаптивність, позитивний досвід, гібридний онлайн-курс.

Introduction. First and foremost, I want to emphasize that the core idea that students' needs, expectations and learning style should always be the highest consideration when determining the best teaching strategy to employ in the classroom. I am confident that today's inter-university online learning is another opportunity for us to network with our like-minded colleagues, to gain ample knowledge and mutually enriching experience that will definitely benefit both the universities and promote our personal growth and generate new ideas. Recently I have bumped into an exciting article that covers the topic quite relevant to our HyFlex learning core idea - 'a globalized world requires educators who are braced to respond to many diverse contextual realities and key concepts - flexibility, adaptability and contextual awareness'. And presently, our Universities have the right time for evolving into the University of Tomorrow through the flexibility offered by the Corona modality.

In his treatise on the future of humanity, 21 Lessons for the 21st Century, the philosopher-historian Yuval Noah Harari predicts that the key 
skills students need to survive and thrive in the 21 st century will be emotional intelligence and the ability to deal with change (O'Keeffe, 2020). Coping with the level of uncertainty will require adaptability and psychological resilience. These are best fostered by an education system that prioritises not traditional academic learning but rather "the four Cs": critical thinking, communication, collaboration and creativity. In my opinion, the role of an educator/teacher in this process is crucial. What is more, the 4Cs of ours are competence, charisma, chemism, and charm.

HyFlex teaching and learning (Case-study of the Department of Modern Foreign Languages \&Translation Studies). To put the topic of benefits of HyFlex learning in creating a positive students' experience, I would like to clarify that Hybrid-flexible courses (aka HyFlex) are popular because they allow students to choose the learning style and environment that works for them on a day-to-day basis. These HyFlex classes are also increasingly a feature of education during the COVID-19 pandemic, as they allow increased social distancing for classroom-based activities, while also allowing students to navigate their personal risk tolerance.

Our first paradigm of HyFlex learning started with EU-funded 'Open Online Course of European Integration: Strategic Communications'. It has given the foundations for the EUROSCI cross-functional team to make decisions that resulted in better development, by doing our Agile, our students helped the other team-members to effectively communicate within our project as well as collaborate, respond to change and make the right decisions and harness a better competitive advantage. As far as Strategic Communication EUROSCI project was built around motivated members, it created favorable environment to support students' needs and trust. It serves as an excellent paradigm to convey the information for our face-toface effective communication (Jean Monnet Open Online Course 20182019).
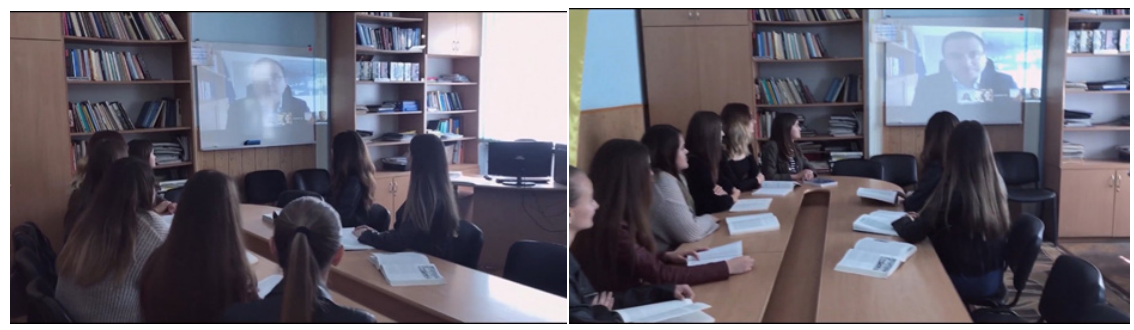
HyFlex classes also allow students to continue to participate in classes even if they are self-isolating due to shifting local regulations or personal exposure situations (in terms of Yuriy Fedkovych Chernivtsi National University, in early September 2019 we were experiencing hybrid system of attending face-to-face and since March 2020 there has been a total shift to online learning, except for temporary face-to-face for 1-and 5-year students).

Noteworthy, while offering HyFlex classes we had to make sure materials and activities were available to students - prospective translators - and help them understand the materials - whether those students are attending in person or virtually. This requires careful lesson planning and an integration of both synchronous and asynchronous online activities into the course on an ongoing basis (MOODLE platform).

Consequently, armed with a can-do spirit, our Department members leaped into hybrid/blending teaching. The top priority was establishing cosy ambience for the students to create their positive experience (with 168 students previously cycling in and out of classroom and virtual course - activities, we made sure that all students in HyFlex classes were able to connect with each other). They still felt the climate of togetherness while attending the classes remotely.

The crux of the HyFlex matter is the assigning group projects as a part of class cohesion. Group projects are a great tool for online classes in general, but they have become particularly critical for Hyflex teaching. Ranging from the first to fourth-year-student groups contained a mix of students in terms of the course attendance strategies. That prevented stratification between in-person and online learners and allowed students to experiment with learning formats they might be less comfortable with. I must confess, owing to students' agility, zealousness and aspirations, I felt quite comfortable in a HyFlex teaching environment, furthermore, teaching them about group dynamics, problem solving, and project management made our journey go smoother.

Noteworthy, another important identiary aspect for our students' translation and interpreting skills

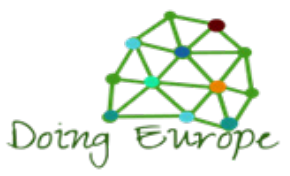
is a two-year truly bountiful cooperation with the EU-funded Jean Monnet course (Havlin, 2020). In addition to the actual subjects of my course - English As a Foreign Language, the 3-year students were the participants of the Joint Hybrid Course Jean- 
Monnet-Course 'European Integration: Conflicts, Institutions, Policies, and Cohesion. Within the framework of the project "Doing Europe: Cohesion and Integration in the European Union"-(611388-EPP-1-2019-1-DEEPPJMO-MODULE.

This online course brings together students from the University of Siegen in Germany and Yuriy Fedkovych Chernivtsi National University in Ukraine. The MOODLE learning platform facilitates this hybrid course and serves as transnational educational base bringing them in dialog across Europe. That hybrid course hasn't just made our group activities more rewarding both for me and my students; it has made us far less stressful and more resilient.

I can't but mention another aspect of our Department's spice and tradition - the Festival of Foreign languages, regularly hold in May, dedicated to the Day of Europe (it's worth mentioning that 6 European languages are taught at our Dept) and during the festival our experts in World Affairs and TS discover their gifts and talents in singing, dancing and performing in different languages. Regrettably, Corona destroyed this tradition as well, but I gave the students a chance to lead and make their sole and team projects related to the topics we covered during the semester and it proved to be the one of the best ways to reinforce learning through teaching. The students were given the opportunity to make their presentations or lead classes segments on particular topics (presenting news, topic-related idioms and slangs; forums on DOEU project) a kind of Pedagogy of Partnership. To the point, we used to allow student-led teaching to take place both in the classroom and virtually. Such strategy includes students in the in-person classroom environment learning from students who may be presenting synchronously via technology from their own home or other remote location.

Their final projects that were to share their experience gained in Coronalearning yielded great fruits and outperformed my expectations. Being tech-savvy, the 1-2 year students shot their studvines or 3-minute videos rich in learnt vocabulary and grammar presentation, filled with bright emotions and sweet memories. The 3-year students shot the video "What is my vision of EU" and even recorded the song "Shallow" and the 4-year students published their third issue of the magazine giving life hacks how to survive the Corona and never stop advancing and mastering English. That was a real blast for me in re-conceptualization of the teaching/learning paradigm. 
A facebook.com

Кафедра сучасних іноземних мов та перекладу Almost 3 month of our "house arrest" have passed. And while World is playing the waiting game, our English group has nothing to do with procrastination. I should say that learning under lockdown and of course our smart, understanding and highly professional tutor\&mentor\&teacher and lovely friend Valentyna Bohatyrets provided us with a unique opportunity to explore our passions and curiosities with a certain vigor that may have been impossible otherwise. Undoubtedly, our university, lecturers and students faced difficulties under the unusual circumstance of quarantine, and everyone was wondering how study habits and academic performance will develop in this strange situation. But every cloud has a silver lining. We met these challenges in a professional manner, learned how to cope with anxiety, think out of the box and stay positive whatever went down. All of us guys are separated only by physical distance, not emotional one. So don't forget about power of positive thinking and good luck on exams.

Special thanks to Tanja Havlin for her engrossing course „Doing Europe" and opportunity to push our boundaries without crossing the borders.
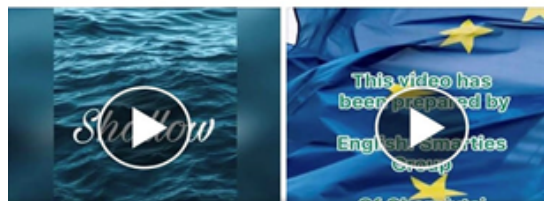

Maria Pylypyuk is with Любомир Скрипчук and 10 others.

* Favourites · 25 May · 6

\#STAYSAFE \#STAYHOME.

We want to start this post exactly with these hashtags and this is why... This university year was extremely challenging and sophisticated for us. Not only because of graduating and becoming real experts, but also because of the lockdown and trying out new system of education from home. Finally, we are approaching to the finish line and in order to summarize what we've experienced throughout the last year, we present the "quarantine edition" of out annual magazine.

Furthermore, we are eager to express our common opinion about auranhiaunmante.

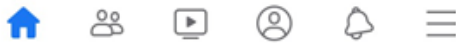

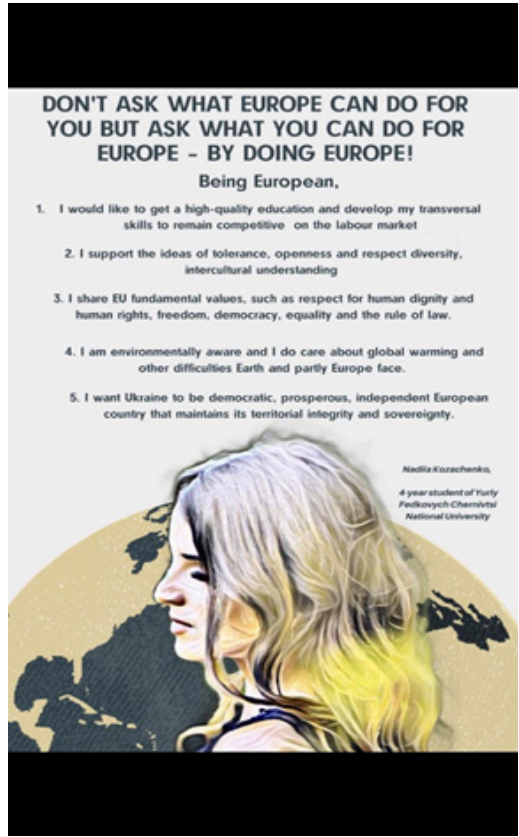

has just began for us."

-"The experience we've gained this year empowers and ignites the desire to learn."

The magazine includes our recommendations for the fellows on how to spend the lockdown period with benefit.

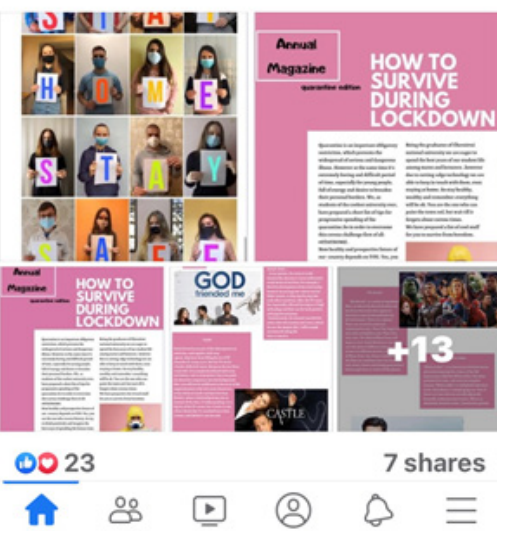


Conclusions. To recapitulate the value of HyFlex learning in creating a positive students' experience, I would emphasize that many are already voicing in favour of its benefits, and in my turn, I am absolutely positive about HyFlex learning that has changed the way of teaching. It has enabled us to reach out to the students more efficiently and effectively through chat groups, video meetings, MOODLE and also document sharing, especially during this pandemic. The students also find it is easier to communicate on (Googlemeet and Zoom). Personally, I will stick to these collaboration and communication software even after Coronavirus, I reckon traditional offline learning and e-learning can go hand by hand via HyFlex. There are, however, challenges to overcome. Some students without reliable internet access and/or technology struggle to participate in digital learning; this gap is seen across countries and between income brackets within countries. While some believe that the unplanned and rapid move to online learning - with no training, insufficient bandwidth, and little preparation - will result in a poor user experience that is unconducive to sustained growth, others believe that a new hybrid model of education will emerge, with significant benefits. I believe that the integration of information technology in education will be further accelerated and that online education will eventually become an integral component of the present-day education. Despite the drawbacks, there are some obvious benefits to leveraging a HyFlex course model. It allows students more flexibility than ever before, meaning they can adjust and adapt as needed to accommodate their schedules. It also gives students access to a greater breadth of learning materials than they would otherwise receive.

Summing up, I'd like to cite Brown "Every learner is unique. Every teacher is unique. And every learner-teacher relationship is unique". What is clear from the pandemic is that ed-tech cannot replace the expertise of teachers but can complement teacher-led learning and support them to deliver their best, whether in the classroom or remotely. This is where leaders have a huge role to play in ensuring that blended approaches are underpinned by tools designed to complement teaching both in and out of the classroom. Add to these personalised technologies that create individual learning experiences for each student and the goal of effective, engaging blended learning or HyFlex is doomed to succeed.

As a result, after Covid-19 the world and education has changed dramatically, with the distinctive rise of e-learning, whereby teaching is undertaken remotely and on digital platforms. This resulted in the largest 
"online movement" in the history of education. Importantly, research suggests that online learning has been shown to increase retention of information, and take less time, meaning the changes Coronavirus have caused might be here to stay. In many ways, HyFlex classes are a crash course, in a particular subject is a short course in which you are taught basic facts or skills, for both students and teachers - in everything virtual learning can bring to both fully-remote and more traditional classroom experiences. Students and instructors alike have the opportunity to stretch and discover what class styles work for them while also gaining valuable skills that will help them navigate today's global labour market.

To crown it all, I am honoured and pleased to have been involved in HyFlex learning and creating students' positive experience and I look forward to developing new patterns of communication with both my colleagues and Gen $\mathrm{Z}$ students.

\section{References:}

172 1. Havlin, T. (SoSe 2020). Jean-Monnet-Seminar - European Integration: Conflicts, Institutions, Policies, and Cohesion. Available at https:// moodle.uni-siegen.de/course/view.php?id=21358

2. Jean Monnet Open Online Course of European Integration: Strategic Communication[website], 2018-19. Available at https://www.eurosci. net/universities/yuriy-fedkovych-chernivtsi-national-university

3. Klimovaa Blanka Frydrychova \&Kacetl Jaroslav (2015). "Hybrid learning and its current role in the teaching of foreign languages". - Procedia - Social and Behavioral Sciences, 182 (2015) 477 - 481. Retrieved from http://www.sciencedirect.com (Accessed June 20, 2020)

4. Mahmoodi-Shahrebabaki M. (2015). "On the Understated and Avant-garde Language Teaching Methods and Theories". Int. J. Appl. Ling. Stud., 4(1): 17-23)

5. Maltese, R. (2020). "5 Tips for Delivering Better Hyflex Teaching Classes". Retrieved from 5 Tips for Delivering Better Hyflex Teaching Classes | Kaltura (Accessed November 12, 2020)

6. O'Keeffe, A. (2020). "Instead of rote learning useless facts, children should be taught wellbeing". Retrieved from https://www.theguardian.com/commentisfree/2020/mar/02/instead-rote-learning-useless-factschildren-need-taught-wellbeing (Accessed May, 20, 2020) 